Western University

Scholarship@Western

Aboriginal Policy Research Consortium International (APRCi)

$6-2011$

\title{
Aboriginal youth, hip hop and the politics of identification
}

George Morgan

Andrew Warren

Follow this and additional works at: https://ir.lib.uwo.ca/aprci

Part of the Other Sociology Commons

Citation of this paper:

Morgan, George and Warren, Andrew, "Aboriginal youth, hip hop and the politics of identification" (2011). Aboriginal Policy Research Consortium International (APRCi). 426.

https://ir.lib.uwo.ca/aprci/426 
This article was downloaded by: [University of Western Ontario]

On: 31 October 2012, At: 05: 34

Publisher: Routledge

Informa Ltd Registered in England and Wales Registered Number: 1072954

Registered office: Mortimer House, 37-41 Mortimer Street, London W1T 3J H, UK

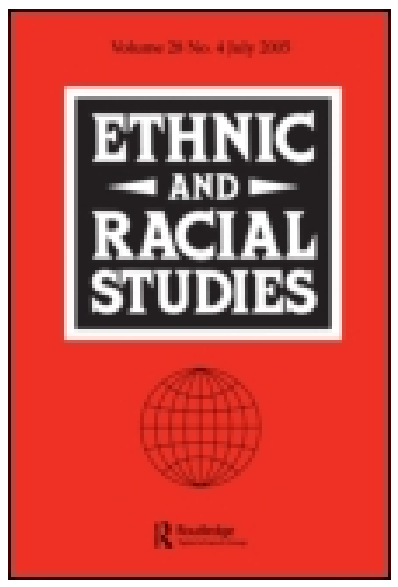

\section{Ethnic and Racial Studies}

Publication details, including instructions for authors and subscription information:

http:/ / www. tandfonline.com/loi/ rers20

\section{Aboriginal youth, hip hop and the politics of identification}

George Morgan \& Andrew Warren

Version of record first published: 29 Oct 2010.

To cite this article: George Morgan \& Andrew Warren (2011): Aboriginal youth, hip hop and the politics of identification, Ethnic and Racial Studies, 34:6, 925-947

To link to this article: http:// dx. doi.org/ 10.1080/01419870.2010.517323

\section{PLEASE SCROLL DOWN FOR ARTICLE}

Full terms and conditions of use: http://www.tandfonline.com/page/termsand-conditions

This article may be used for research, teaching, and private study purposes. Any substantial or systematic reproduction, redistribution, reselling, loan, sublicensing, systematic supply, or distribution in any form to anyone is expressly forbidden.

The publisher does not give any warranty express or implied or make any representation that the contents will be complete or accurate or up to date. The accuracy of any instructions, formulae, and drug doses should be independently verified with primary sources. The publisher shall not be liable for any loss, actions, claims, proceedings, demand, or costs or damages whatsoever or howsoever caused arising directly or indirectly in connection with or arising out of the use of this material. 


\title{
Aboriginal youth, hip hop and the politics of identification
}

\author{
George Morgan and Andrew Warren
}

(First submitted February 2010; First published October 2010)

\begin{abstract}
This paper explores the identity work taking place around contemporary subcultural hip hop amongst Australian indigenous youth in two disadvantaged urban locations. Previous work on Aboriginal hip hop has been attentive to the interface between tradition and modernity. However, existing scholarship has lacked a deeper ethnographic understanding of the dynamics between youth and parent cultures, and the tensions between the two generations. This article is based on research with young hip hop enthusiasts, community activists and educators. It deals with the cultural politics of identification and sees hip hop practice as associated with a process in which Aboriginality is crystallized as a principal affiliation and as offering an account for experiences of social marginalization. Far from being an outlet for expressing a prior or essential Aboriginality, hip hop as cultural practice is associated with the production of particular identifications.
\end{abstract}

Keywords: Aboriginal; Australia; youth; identity politics; cities; cultural hybridity; essentialism.

\section{Introduction}

There is a vast literature on the fragmentation and dissipation of social roles characteristic of modernity (Giddens 1991; Beck 1992) and the waning of bonds associated with traditional communities. As citizens of modern societies we are situated in webs of relationships and structures that can place us simultaneously in a range of categories worker, immigrant, tenant, client of the state, etc. - that cut across each other and play a greater or lesser role in shaping us as social actors. ${ }^{1}$ Such categories can provide the foundation for solidarities and political action, but do not always do so. In discussing identity politics, several 
writers have criticized the tendency of academic analysts to read off 'identity' from objective structural situations and to take at face value the claims of political leaders to represent those who share a common objective situation (Brubaker and Cooper 2000; Fraser 2000). A better concept is that of identification: the processes by which particular identity positions come to achieve a subjective centrality, to operate as 'master codes' in shaping social actors and their public roles at particular moments. Identification is not an inevitable consequence of inhabiting a structural situation; this requires the performance of identity work in the fields of culture and politics.

This paper explores identity work that takes place around contemporary subcultural creativity - hip hop - amongst those who come from Aboriginal family backgrounds and who have grown up in urban settings. We focus on two locations - the deprived neighbourhoods of Redfern and Waterloo (RW), in inner Sydney, and Nowra, on the south coast of New South Wales - and on groups of young men who have participated in hip hop - workshops/training, production, performance. We argue that this participation helps to foreground their Aboriginality both as a principal affiliation and as offering an account for their experience of social marginalization. Far from providing a subcultural outlet for expressing a pre-constituted or essential Aboriginality, hip hop is associated with identity work, with encouragement towards particular identifications. As a field of creative expression it is deeply influenced by efforts of (sub)cultural and community leaders to produce and reproduce Indigenous communal bonds. However there is no consensus around the nature of those bonds and political dispositions that flow from them. Indeed there are struggles over what Aboriginal hip hop means and what is authentic and culturally worthy.

\section{Subculture and the local work of transformation}

Hip hop consists of four ingredients - rapping (MCing), deejaying, break dancing and graffiti art (Kitwana 2003) - but it also contains elements of dress and language (Alim 2007). At grassroots level hip hop is produced by rapping to a beat, created by the Deejay, who produces a rhythmic tune, mixing and dubbing sounds and old records together. The beat can be both original and borrowed. For emerging, improvised and vernacular styles of hip hop, like beat-boxing, there is no need for expensive deejay equipment. Instead the MC rhymes to a vocal beat produced using the mouth, lips, tongue and voice. Computer programs, like Fruity Loops, ACID, Reason and Adobe, also enable beats and raps to be created, recorded and burnt onto CD format.

Most academic analysts who have charted the way hip hop has been taken up by disenfranchised youth (Mitchell 2002; Alim, Ibrahim and 
Pennycook 2009) see it not as exemplifying American cultural dominance, but as the quintessentially 'glocal' subculture, one which demonstrates the ways global concerns are grounded in local contexts and cultures. In their work on Aboriginal music, Dunbar-Hall and Gibson (2004) use 'transnational black culture' to theorize the uptake of American hip hop styles, particularly gangster framed rap, by Indigenous Australians, especially youth. When performing in Australia, artists like Snoop Dogg and Ice Cube have made efforts to connect with local Aboriginal populations, referring to cultural similarities during interviews and gigs, while making contact with communities, as Snoop Dogg did when he visited Redfern in 2008.

The term creolization (Hannerz 1992, pp. 264-7) best describes the way a subcultural form originating amongst Afro American youth is transformed into local idioms. This is not a simple mixing process but one in which the received forms are actively processed through the grammar and morphology of the receiving language. Willis writes about 'grounded aesthetics', suggesting that cultural consumption is always an active process involving practices and meaning making (Willis 1990). We all transform and make local sense out of cultural texts produced by other people in other places.

This idea of cultural transformation as an inherent process of the modern world poses a challenge to the definition of Indigenous cultures as fixed to primordial traditions. Much of the writing on postcolonialism stresses the capacity of Indigenous peoples to adapt and

Figure 1. Snoop Dogg visits Redfern (Sydney Morning Herald, 31 October 2008).

Photo: James Brickwood.

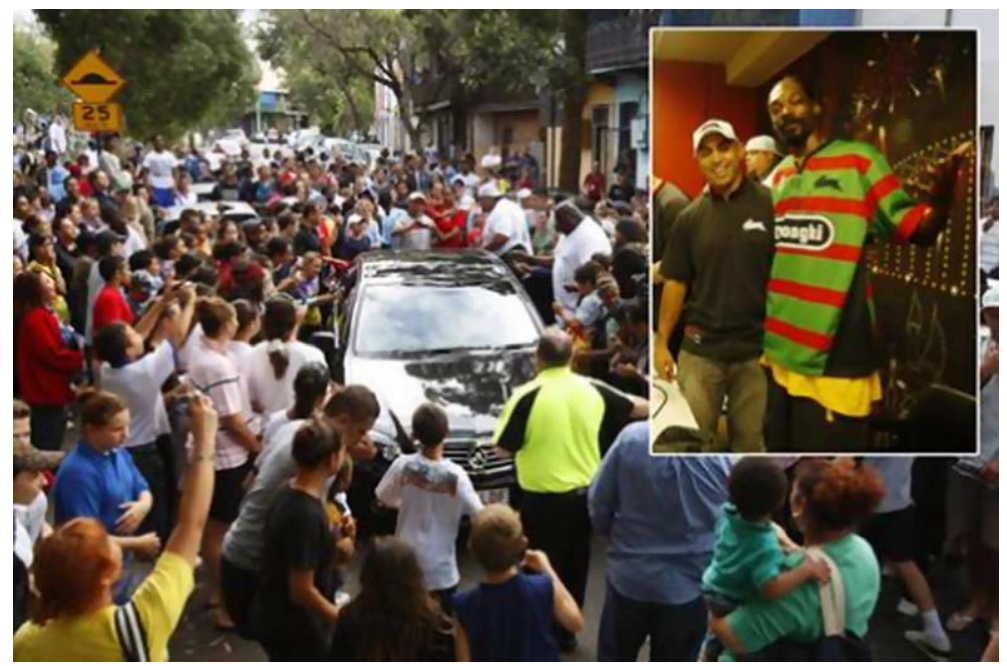


incorporate in the face of colonial cultural dominance, while not surrendering to the pressures for assimilation (Thomas 1991). Indeed the notion of pre-colonial cultures as timeless is a romantic Western construction of Indigenous peoples. Certainly those who adopt the cultural salvage approach of Aboriginality, who value only that which appears to be immune from contemporary influences, see little cultural worth in hip hop.

The interface between tradition and modernity has been a central preoccupation of those who have written about Aboriginal hip hop. Stavrias correctly observes that Aboriginal culture is not static but, like all cultural forms, open to negotiation, and that 'hip hop is a powerful tool in helping Aboriginal youth with this negotiation [between tradition and modernity]' (2005, p. 52). Notarpietro-Clarke argues that hip hop involves 'incorporation of traditional rituals and practices into more global techniques such as MCing, breaking and freestylin" (2007, p. 42). In his short history of Aboriginal hip hop Mitchell concludes that 'hip hop's affinities with Aboriginal cultural forms makes it an ideal means for youth to get in touch with their tribal identity, history and cultural background' (2006, p. 136). Each of these writers recognizes that mentoring is a central part of Aboriginal hip hop. They all acknowledge the pedagogical role of artists like Wire MC, Local Knowledge and Brothablack. Most young people began by listening to mainstream American rappers; yet hip hop mentors encourage young Aboriginal people to produce and perform their own music - describing and reacting to everyday local oppressions and to pay homage to histories of Aboriginal resistance and traditional culture.

Much scholarship on Aboriginal hip hop, however, lacks a deeper ethnographic understanding of the dynamics between youth and parent cultures, and the tensions that might exist between the two. An exception is the work of Dawes (1998), who studied a group of young Aboriginal men from North Queensland involved in early hip hop subculture, particularly street art. This illicit practice formed part of a structure of resistance to regimes of corporeal regulation/ governance. Importantly, Dawes identified their enthusiasm for 'Afro American rap groups such as Public Enemy, Ice-T or Run DMC'. He wondered why the young people he observed showed less enthusiasm for 'Aboriginal groups who wrote and sang about current political issues. Ricardo stated that, "I listen to some of them groups sometimes but I'm really not into that political stuff ..." (Dawes 1998, p. 31). This is symptomatic of intergenerational tensions, of the ways Aboriginal youth resist the cultural and political expression characteristic of the parent generation. Dawes states that, 'the multiple subjectivities of Aboriginal and Torres Strait Islander youth are located not only in traditional Indigenous culture but also anchored 
in ... youth culture' (1998, p. 32). He argues that Indigenous people do not share a singular 'consciousness or world view' (p. 32), that it is wrong to see Aboriginality as being based on a 'generalised culture ... passed on from one generation to another as a form of social inheritance' (p. 33).

Dawes's work aside, in much of what has been written about Aboriginal youth cultures insufficient attention has been paid to the complexities of identity work and the politics associated with this creative practice. In common with local expressions elsewhere in the world, Aboriginal hip hop is not a singular form, but variegated in its political and social messages. The genre ranges from representations of declamatory and angry masculinity to music with gentle conformist messages stressing the importance of education, individual ambition and respect. Its political meaning is neither singular nor consensual. Indeed, as we shall see, there are struggles over the meaning of hip hop: both over what constitutes authentic Aboriginal style, what sort of political orientation to colonialism it presents, and what effect it has on social bonds. But most importantly, our work reveals how hip hop mentoring encourages the view that Aboriginality is the central plank of identity.

We differ from most who have written about Aboriginal hip hop in that we see it not as the expression of an essential or intrinsic Aboriginality in the idiom of a contemporary youth culture (see also White 2009). These writers imply that identification is a sort of developmental inevitability, an inexorable recognition of essential self. By contrast we argue that far from providing a receptacle for public expression of a pre-existing Aboriginality, hip hop mentors are engaged in the practice of identity work; in foregrounding Indigenous identification and thereby reproducing communal solidarities and, through those, encouraging particular orientations to post-colonial politics. Despite the growing body of hip hop work, analysis has lacked deeper engagement, particularly with budding young rappers. Our research fills this gap, outlining the stories and experiences of hip hop enthusiasts who identify as Aboriginal.

This article is based on field work in RW and Nowra. The RW work involved semi-structured interviews with six young Aboriginal hip hop enthusiasts (two of whom are discussed below). This was supplemented by interviews with a number of older Aboriginal community leaders/activists, members of the pre-hip hop generation, in which they discussed their feelings about the way hip hop shapes the outlook and dispositions of young Aboriginal men. The Nowra research involved semi-structured interviews and participant observation to examine cultural experiences and performances of young Indigenous hip hoppers. A research diary was also kept, reflecting on participant 
observation during performances, with reflection on interviews, informal meetings and catch-ups with respondents.

For both RW and Nowra, narrative analysis was used to analyse interview transcripts, research diary notes and participants' music. Appropriate for this work as it is sensitive to individual stories, a narrative analysis allows respondents to build up their own hip hop beliefs, ideas, networks and knowledge (see Wiles, Rosenberg and Kearns 2005). In our approach, analysis occurred where several narratives were used as case studies to demonstrate different perspectives of the same conceptual outcome (see Gorman-Murray 2006). This method is particularly suitable for empirical research exploring youthful Indigenous hip hop and notions of Aboriginality from two stigmatized urban locations.

\section{Criticisms of identity politics}

Recently a number of academic commentators have criticized social movement politics for their reductionism, particularly where those politics work with essentialist ideas of identity. Nancy Fraser (2000), for example, argues that identity politics often foregrounds the quest for recognition at the expense of the need for redistributive justice. She states that,

the identity model serves as a vehicle for misrecognition: in reifying group identity, it ends by obscuring the politics of cultural identification, the struggles within the group for the authority and the power - to represent it... The identity model thus lends itself all too easily to repressive forms of communitarianism ... this sort of identity politics scarcely fosters social interaction across differences: on the contrary, it encourages separatism and group enclaves. (Fraser 2000, pp. 112-13)

Iris Marion Young's (1990) work is also critical of communitarianism and the closures associated with identity politics. She wrote that the idea of a 'society as composed of decentralized, economically self sufficient, face-to-face communities, functioning as autonomous political entities does not purify politics, as its proponents think, but rather avoids politics' (Young 1990, p. 259). Brubaker and Cooper stress the need to distinguish between categories of political practice and those of analysis (2000, p. 4). This means critically analysing the claims of those who purport to represent a constituency defined by an objective identity position. They argue that much political sociology conflates categorization with 'its presumed result, identity' (p. 26). Group identification cannot simply be inferred in this way, but rather we should explore the 'contingent and variable relationship between 
mere categories and bounded solidarity groups' (p. 9). Elsewhere, Brubaker et al. (2006) apply these ideas to the politics of ethnicity. They observe the often partial and weak identification of the Hungarian minority in the Romanian city of Cluj with the rhetoric of political representatives. 'Groupness', Brubaker suggests elsewhere, is something that happens, or 'may not happen ... high levels of groupness may fail to crystallize despite the group-making efforts of ethnopolitical entrepreneurs' (Brubaker 2004, p. 54). Lazy use of the term identity may lead us to 'neglect the everyday contexts in which ethnic and national categories take on meaning and the processes through which ethnicity actually "works" in everyday life' (p. 62).

So those of us seeking to understand group formation and identification should not confine our investigations to politics, to the formal debates being waged within the public sphere. Equally important is the cultural field: everyday culture practice including, but not restricted to, that which happens around the consumption of cultural (and subcultural) commodities. Cultural studies (Hall and Jefferson 1976; Willis 1990) has long been sensitive to wider social and political implications of creative/symbolic practice, and youth subculture has been a particular focus of academic attention (Hebdige 1979). Some commentators (Thornton 1996; Bennett and KahnHarris 2004) have questioned the tendency to over-read the political significance of subcultural practice and suggest the internal dynamics and status hierarchies of youth groups are more significant than broader influences of class, gender and ethnic politics. The work of others (e.g. Shildrick and MacDonald 2006; Nayak 2003) perseveres with the framework developed through the work of the Birmingham Centre for Contemporary Cultural Studies (Hall and Jefferson 1976) in continuing to attend to the ways social structures shape youth cultures. We find this approach useful for understanding Indigenous hip hop. It is important, however, to recognize the social structures whereby aesthetics are grounded (in Willis's (1990) terms). Hip hop subcultures involve patterns of mentoring, informal pedagogies, through which global cultures are grounded in Indigenous expression. Our argument is that this is simultaneously associated with the production of Indigenous identity and the reproduction of groups.

\section{Redfern-Waterloo, hip hop and politics of identification}

Sydney, like many cities in the Western world, has undergone a transition from an old manufacturing-based economy to a new service/ technology/knowledge creative economy. The problem for young people, in particular for young men from working-class and minority groups, is that pathways into productive work are not all that clear. The history of Redfern, adjacent to the city's CBD, is of an area of 
poor housing accommodating largely the Irish Catholic working class and, at various times, ethnic minority groups (notably Lebanese). Importantly the area is the hub and centre of the NSW Aboriginal community, the site of chain migration from rural areas from the midtwentieth century and the base for the establishment of Pan Aboriginal politics (Anderson 1993; Morgan 2006; Shaw 2008). Redfern has long been (and still is) a meeting place, the symbolic heart of Aboriginal Sydney. The contiguous suburb of Waterloo has large areas of public housing accommodating a sizeable Aboriginal minority and there is considerable interchange between Indigenous youth in the two areas. In view of this and the fact that the entire area now comes under the purview of a single statutory authority charged with redevelopment, it seemed appropriate to aggregate them for the purposes of this research.

Among Aboriginal people in RW there are very high levels of addiction, family breakdown, incarceration, mortality and unemployment. Indigenous youth unemployment levels are particularly high (16 per cent in Redfern and 33 per cent in Waterloo), and low levels of workforce participation hide a much more substantial problem of long-term unemployment and welfare reliance (RWA 2006). This problem is particularly acute for young Aboriginal men. There are several reasons for this:

1. Their low levels of participation in formal education mean young Aboriginal men lack credentials to be competitive in the job market.

2. Many have grown up in family/community contexts in which longterm unemployment is the norm. They have few role models (particularly male role models) that would encourage them to develop ambitions, work habits and life skills commensurate with steady employment.

3. There has been a steady erosion of traditional male jobs (manufacturing trade, agricultural/pastoral work, etc.). The parallel growth in service industries is of little benefit to young Aboriginal men because employment in these sectors is largely feminized (McDowell 2003; Watson et al. 2003).

Unemployment also results from an inability to form individual narratives of aspiration, to see pathways into the adult world. This is a significant problem for young Aboriginal men who have left school early, branded as failures, and for whom peer-group activities (some of which are illegal and/or dangerous) are more attractive than is the world of formal education or work. Street solidarities often lead to conflicts with police and authorities. 


\section{Living the history of hip hop}

Rick is 28 and tells us he is Wiradjuri. This means that, following the traditional matrilineal system of his people, he comes from the land of his mother. Wiradjuri country stretches west from the Great Dividing Range in New South Wales, north to the town of Nyngan and south to the Murray River. Rick's father's people are Kamilaroi and their country is in the state's north-west. Like all of our interviewees, and the great majority of Aboriginal people living in south-eastern Australia, Rick's family/forebears ceased to practise traditional lifestyles and speak their language many years ago. Rick grew up and spent most of his childhood living in the RW area, in public housing. In his mid-twenties he spent time in gaol for assault. His parents were radical Aboriginal activists and Rick was frequently in conflict with teachers at school, being expelled from two high schools. His parents and other relatives challenged what they thought was entrenched racism in the school:

I experienced a lot of racism I suppose growing up... I was in kindergarten in year one at Alexandria Public School and my mother said she took me out of that school because of the racist attitude of certain teachers ...

They were also prepared to challenge what they saw as racist curricula:

[My aunty] went down to the school and slammed the books onto the desk in front of the teacher and said that they would burn those books and stuff if they persisted to use those books ... Yeah they were very proactive when we were young ...

Rick described his own youthful resistance and alienation from formal education. While he recognized that there were good teachers who encouraged him, he acknowledged their task was not easy:

I don't think I was the perfect child ... I believe I had a sense of rebellion at a young age, I mean like a lot of children and me personally I believe that children are intelligent it is just that they don't have the vocabulary to express their intelligence, and I was very aware of things at a young age and it didn't take a rocket scientist to know that we had grown up in a racist country ...

With older brothers listening to early hip hop, Rick recalls being captivated by the genre at a young age: 'they were big fans of Run DMC and Beastie Boys and LL Cool J... so in turn I just became a fan of rap 
and stuff. I remember listening to it when I was six years old...' This led him into break dancing:

Yeah all the older boys were always doing it in the lounge room or doing it at school in the hall, as soon as we could get you know a wax floor like a basketball court or a hall ... we were big with the break dancing and stuff and then as I got older I remember round about 87 or 88 I think it was $87 \ldots$ the first NWA CD came out straight out of Compton and I remember I stole ... the tape and I heard what they were talking about and it just spun me out because these people were using a lot of profanity ... it was a bit of a revelation to me at the time, I remember being very naive when I was a child, even though I was very much aware of you know police brutality against me even at that age, I remember being assaulted by police at the age of seven and eight, but ... the Waterloo resident kids we just accepted that that was what coppers did to us.

Rick's comments demonstrate that West Coast rap had a profound resonance with Aboriginal youth in RW. Hip hop was not just a fad the naïve and uncritical consumption of imported youth subculture. Rather it provided an account of urban racism, police persecution and the sense of living in a ghetto. It revealed that black men elsewhere had a similar experience with state authority and fought against it. Not for the first time youth culture built a symbolic bridge between Afro America and Indigenous Australia. The appeal was particularly strong for young Aboriginal men who, much more than women, were at the sharp end of zero tolerance policing and for whom the bonds of citizenship had little appeal. Their sense of being outlaws in the imagined community was also manifested in their sporting enthusiasm. Rick told us, "we were big supporters of the West Indies Cricket Team', emphasizing resistance to the iconic national sporting heroes.

Rick's remarks indicate that their hip hop enthusiasm was not only a cultural response to police, teachers and others with formal authority over them. It also signalled a break from the parent culture:

I. So what did your parents think about that ... do you remember?

R. I think they thought it was mediocre ... just another fad it was just something that the kids were doing ...

I. Did they see the political nature...?

R. I don't think they appreciated it ... I think my parents were too busy you know for a lot of things, like when we were younger we couldn't do a lot of things that other kids did and we couldn't get a lot of things other kids got and we had to go without sometimes, we just had to understand that our parents were who they were and you know there were more pressing issues at the 
time and we had to forfeit a lot of things, or we had to sacrifice a lot of things because of that.

These last remarks appear to be judiciously stated and from the vantage point of one who is now coming to see the point of organized political protest in contrast to the anarchic gangsta/urban guerrilla messages communicated by the West Coast rappers he admired.

\section{Hip hop and identity work}

Trent's life experiences are typical of young Aboriginal men in RW. He was raised in the city, along with several siblings, by a single mother, a Kamilaroi woman from Coonabarrabran (in north-western NSW), having little contact with his father, a Yorta Yorta man from the Murray River region around the Victorian border: 'No I don't really see much of him now, I go down there he is usually roaming around Victoria.' A good pupil during primary school, Trent changed when he entered high school: 'Yeah I stuck to my work until I got to high school and then I started mucking up.' He joined up with other young men on the streets of RW, got in trouble with the police and was eventually expelled from school.

Unemployed and with little conventional ambition, Trent was introduced to Wire MC, an Aboriginal hip hop performer and teacher. Wire encouraged Trent to get involved in music through the local community centre in which a recording studio and rehearsal facilities were located:

I. So tell me how he got you into it. What did he do?

T. I don't know ... I knew him for a while but he didn't know I done that kind of stuff, I said I had done that kind of stuff (before) and he said oh yeah sweet just come along and just get into it ...

This pattern of recruitment to a subcultural 'community of practice' was common to those involved in this activity in both RW and Nowra. Unlike the legal and institutional compulsion associated with formal education, creative endeavours arise from existing informal networks:

I. ... So he showed you some of the techniques?

T. Yeah, he does mostly everything for me.

I. Right, so you have made a CD...?

T. Yeah I am working on one now, but I have made a couple of tracks here and there but I haven't really made an album but that is what we are working on now.

I2. Do you write your own stuff? 
T. Yeah I write my own stuff, we are going to bring out this little group like a little rap team so we are going to call ourselves something but we are still thinking ...

I. So is it all Koori kids?

T. Yeah ... there is two other fellas I sing with and we just basically just get up there ... I2. Muck around you reckon...

T. Yeah muck around ...

I. What kind of message comes through in your songs?

T. I mostly write about black people and my background and all that.

I2. How do you feel about that though, like you can rap about it but, what are you trying to communicate, like you are pissed off about stuff or...?

T. Yeah like that back in the day land rights and that stuff I mention that...

Trent's experiences illustrate some of the central elements of our argument: (1) Young Aboriginal men who resist formal educational settings often thrive in informal settings, particularly participating in communities of practice with their peers. (2) Contemporary youth cultural projects are often most successful when they draw on subcultural/street culture enthusiasms. Such projects can provide forms of institutional support for cultural production (equipment, payment for teachers/mentors). They constitute gathering places for young people that contrast with the rigid compulsions of schools. Additionally, they provide alternatives to those resistant street activities which are dangerous, illegal, or both. (3) Cultural brokers like Wire MC encourage young men to see hip hop not just in its Afro American form but as a vehicle for handling the contradictions in their own lives. They nurture the symbolic expression of Indigenous resistance and survival, teach about history of struggle and encourage stronger identification than the young Aboriginal men might otherwise experience. Trent's last sentence ('land rights and that stuff') is delivered almost as a deferential gesture, an afterthought, indicating that, like many young Aboriginal men, this is not a history that has captivated and defined him. However, continued participation in activities of this sort might strengthen his identification, as it did for Rick.

\section{Nowra and Aboriginal youth}

Nowra is a small city of 30,000 , on the south coast of NSW, with 6 per cent of the population Indigenous - a high proportion compared with state and national figures ( 2.1 per cent and 2.3 per cent respectively). 
During the summer the population of the city bulges as tourists pass through, accessing holiday spots in nearby Jervis Bay, Sussex Inlet and Ulladulla. Yet seasonal tourist traffic has brought Nowra limited economic or social benefit. Being inland, it has shared less in tourism, instead constituting a regional service and retail centre along the major highway. It is a place characterized by high youth unemployment levels, out-migration and welfare dependence (ABS 2006). Only 16 per cent of Nowra's Aboriginal youth complete year 12, compared with 31 per cent for non-Indigenous youth, alarmingly contrasted with national averages of 42 per cent. Unemployment amongst Indigenous people is 22 per cent, with a third of Indigenous youth aged 15 to 24 unemployed.

Another concerning feature of Nowra is the 'substantial net outmigration among those of school leaving age' (Shoalhaven Council EDS 2005). Between 2001 and 2006 more than 10 per cent of Nowra's youth moved away, seeking employment and a better quality of life. Sydney, $170 \mathrm{~km}$ north, is too far for commuting to work or to socialize, so the best option becomes relocation. At the margins of economic growth and social life, Nowra is a city facing complex problems, including racial tensions, related to high rates of crime and violence across parts of the town, particularly East Nowra, where nearly 20 per cent of the population is Indigenous. Indigenous youth in the town are commonly depicted as delinquent, idle, and troublesome.

It is against this socio-economic and discursive background that we explore Nowra hip hop, practised by a group of young Indigenous men. The stories of each indicate that hip hop subculture has not emerged in isolation, but via networks, and practices, supported through a local youth centre, tutoring and informal pedagogies from experienced Indigenous rappers. These key figures have provided energy for subcultural participation and performance, simultaneously informing ideas of what it means to be a young Aboriginal person living in a disadvantaged urban setting.

\section{'Getting in to hip hop'}

Hip hop music, described by Cam as a 'way to express yourself and what's going down in your life', is orally expressive, creative and confrontational. For Corey, aged 19, Nat, 21, and Cam, 22, hip hop participation has helped to negotiate problems faced at high school, depicted as a place fostering racial notions of Aboriginality, tied into ideas of skin colour and racial purity. Corey began performing as an Aboriginal dancer, before progressing into hip hop after watching his cousins' group perform: 
I was, going through school getting in trouble, and I had this teacher's aide come, ... [pause] ... and we rang my cousin, and got a little dance program started up. I started dancing and yeah, it kept me out of trouble. I'd been dancing for a few years, and yeah then I seen my cousin Selway and he had this little Aboriginal rap group [East Coast Productions] ... I thought that's mad, a few years on, he started getting really good. I thought I wanna start doing that. He gave me this program, to make beats on the computer, and taught me some stuff, showed me some things ... yeah so once I had a few beats I came down here [Nowra Youth Centre], mucking around with some of the local boys, rapping, I was just mucking around, and yeah we started getting serious and started getting good. (Corey)

Corey, aka Yung Nooky, credited his teacher's aide along with his older cousins Cecil and Selway for supporting his initial participation in dancing and hip hop. Corey and his friends had enjoyed listening to American hip hop, particularly fond of Ice Cube; yet once aware of more local, cultural styles, an enthusiasm for practising the music was invoked. The Nowra youth centre became a relevant place for 'getting in to hip hop' (Cam). It was a space utilized by a mixture of youthful bodies, 'young Kooris and white fellas' (Nat). For Corey, performing and practising hip hop was fresh and exciting. It was also where he began to galvanize his Aboriginality, investigating his cultural background before writing raps about experiences of cultural history, racial prejudice and formation of social bonds with other young Aboriginal men. When participants 'began to get serious about things' (Cam), well-known Indigenous musicians became valuable for understanding Aboriginal culture, through lyrics and punchy beats:

I remember ... I would listen to the music ... and mainly American rappers. Then after listening, watching and ... learning off Aboriginal guys like Wire, my mates thought yeah let's have a go, so we worked on getting some original beats and once we had them we would rap to the beat ... our raps, just talk about life around here for young Kooris, gets pretty frustrating sometimes. (Nat)

While black African-American rappers often rhymed about bling, pimpin' and urban gang life, Indigenous participants were encouraged to develop their own anomalous beats and lyrics, drawing on individual experiences and passions as Aboriginal youth living in a city of disadvantage. 


\section{Subcultural pedagogies}

Nowra's hip hop scene demonstrates how specific informal pedagogies are central in the formation of collective youth solidarities and selfunderstandings. This informal 'schooling' was led by established and recognized Indigenous performers. According to Cam, performers he admired and 'looked up to ... were Wire MC, Brotha Black, Choo Choo, and Street Warriors ... mainly the Indigenous guys'. Not only did they listen to their music online via MySpace or YouTube (http://

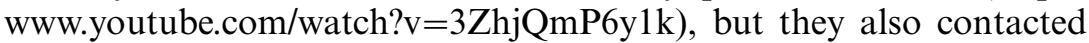
and worked with these performers at locally organized workshops and Aboriginal community events. In particular, Wire MC had collaborated with Corey on several songs, where he would sit down and work through rap verses, asking questions about where inspiration for a song developed, providing feedback and encouragement on content and vocal style, even giving impromptu performances to demonstrate how a beat or rap could be improved. This interaction was personal, intimate and based on cultural and emotional bonds of trust and respect.

After developing rapping, beat-making and dancing skills, some participants formed a rap group, calling themselves 'Yuin Soldiers', a name which holds significance for the young Aboriginal men. The Yuin people are considered traditional owners of the land and water, from Merimbula in the south to Port Jackson in the north. Corey explained the importance of the group's name:

You see Yuin represents our people the traditional owners of the land ... coastal people ... and soldiers keep fighting and never give up so that's where the name comes from.

According to Corey, Yuin Soldiers drew inspiration from Indigenous performers like Local Knowledge (now separated into two groups, Street Warriors and The Last Kinection) and Wire MC. These were artists who advocated in their own songs and during collaborative performances, 'respect for your tradition, your land, your brothers and family' (Cam).

While participants spoke of wanting to produce their own distinctive music, their lyrics remained positioned around 'talking about pride and our culture and also like racism you experienced at school or around town' (Nat). Participants working and collaborating with Indigenous and non-Indigenous musicians demonstrated a sense of self-affiliation, paradoxically instilled through groupness, solidarity and brotherhood. Hip hop was rarely practised alone or individually, despite it being canvassed as a way to create an individual sense of self (see Stavrias 2005). Hip hop in Nowra was emphasized as an 
interactive, mediated process, through which solidarities and selfunderstandings were developed. Popular Indigenous artists gave performative and expressive guidance, motivation, education, support and encouragement. Nat and Corey spoke proudly of being able to perform alongside Wire MC at a local Aboriginal event:

Yeah I performed with Wire MC at Sandon Point (Wollongong), for an Aboriginal protest against developing houses there, which is an Aboriginal site. That was a big thrill for me to perform with him at that place; I really like his music, the message and, yeah and what he does for us. (Corey)

Through contacts with 'more established' Indigenous rappers, Aboriginality was affirmed, not as a fixed or pre-determined identification, but constituted in a narrative process. Hip hop 'Aboriginal' style was depicted as a contraposition to a mainstream or colonial style:

Australian hip-hop is too preoccupied with getting mainstream support. For myself personally, I don't give a fuck about mainstream support because I come from a place where the mainstream has never supported me anyway. And like I said, I don't do this to advance hiphop; I do it to advance my self as a human and as an Aboriginal, advance the awareness of my culture, especially on a contemporary tip. As for the black and white sides of hip-hop coming together through someone like The Herd and Local Knowledge, it's a great thing, but I can also see it being flipped, in the sense that 'Oh look, we've got a black hip-hop crew and a white hip-hop crew getting together. It's all fine'. (Wire MC, Local Noise 2006)

Wire MC describes his hip hop as a vehicle to progress Aboriginal culture. Simultaneously, he delineates mainstream as a non-Aboriginal otherness, implicitly detached from 'his' culture. Brothers Warwick and Abie Wright, from Street Warriors, depicted by participants as 'inspiration', also confirmed Aboriginality anchored within doctrines of solidarity and groupness. At the same time, Aboriginality was presented as identification contrasted to the mainstream:

So all my mob you know this rhyme it be for you

So now you hearing a brother and his lyrics be louder, about my race Aborigine

I'm so fuckin proud ah,

And if your still not sure whose the deadliest race ey, Then come welcome all and we'll say it to your face,

I'm Aborigine, can't you see, young black and proud so fucking look at me. 
Comin out of the land down under, the mighty Street Warrior tribe, This is a dedication to all my fellow soldiers, rest in peace,

Whose land? My land don't you forget it man. (x 3)

(Street Warriors - Abie and Warwick Wright)

These hip hop artists are adopted by the young rappers as celebrated Aboriginal identities. The collaboration at workshops and local performances inspired participants not only in their hip hop performances, but in their identification with Aboriginal culture:

I just look up to the Indigenous guys; cause they're doing something positive for us and our culture. They teach you and you listen to what they say, like be proud to be Aboriginal brother, and not shamed about it. With your hip hop it makes you more confident. (Cam)

While the 'teaching' referred to by Cam included development of specific musical skills, it extended to demonstrations of traditional Aboriginal dances - like the 'Shake a leg' - traditional stories about country and culture, even 'chats' about the older Aboriginal men's experiences, problems and issues. This association is neatly highlighted in the music of Yuin Soldiers, which draws lyrical and implied comparisons with the music of Street Warriors and Wire MC:

Again I must impress I ain't ashamed of what I is,

As a kid growing up in the mission - Nowra,

Still singin that song,

Black boy, Black boy,

The colour of my skin is my pride and joy,

Even awake I'm still dreaming.

In both Nowra and RW, participants had become alienated from, and resistant to, formal pedagogy experienced at school. Thus hip hop and its practices evoked solidarity and brotherhood between young Aboriginal men facing urban disadvantage and stigmatism. The role of mentorship by established and credible Indigenous performers and rappers then became crucial, crystallizing notions of, and identification with, Aboriginality as cultural brotherhood, in the process connecting youth with parent generations. Beats, rhymes and movements enabled participants to confront prejudice experienced at school or on the streets, and to inspire a sense of love for culture and country.

\section{Struggles over the meaning of hip hop: notes from the field}

RW is a political and cultural centre for Aboriginal people. It is the base of Redfern Records and Koori Radio, both of which promote 
Indigenous hip hop artists and their music. It is also the centre for Aboriginal community organizations of various sorts - education, health, legal, cultural - and as such it is a key site for the constitution of Aboriginal identities. We talked to three Aboriginal activists about the political role they saw hip hop as playing.

\section{Scene 1}

Vince is Rick's father (see above). Although his son recalled that in the 1980s Vince had no interest in hip hop, he now sees it as culturally and politically important. In his late sixties, Vince is a veteran of numerous political campaigns going back to the 1960s. We speak to him about politics and protest music, to start a research conversation about the cultural radicalism of his youth and that of today. He shares some thoughts on early Aboriginal rock and reggae music and discusses the influence on him of bands that had marginal influence and popularity in the wider community - No Fixed Address, The Warumpi Band, Black Lace. But he is an activist and also has his own agenda. He is hoping to organize and stage a national Aboriginal hip hop festival and wants to enlist our support. He hopes we might be able to procure university funding to support such an event which he wishes to stage in Canberra, the national capital and seat of political power. When it is suggested that RW might be a more appropriate venue, he responds bluntly: 'I've been doing this for forty years and I know that Canberra's the best place to get our message out there.' We argue that the area's iconic status and its central role in Aboriginal youth culture mean it is likely to draw more participants and larger audiences, particularly given the process of change it is undergoing, but he tells us we are wrong. Vince then expands on his theory that hip hop represents a continuation of the radical tradition of protest music going back to the 1960s and is an outlet for the expression of insurrectionary feelings by people denied land and sovereignty (White 2008). His is the language of conflict politics, not the revisionism and compromise of the Indigenous bureaucratic class.

Later, reflecting on the exchange, we consider Vince's role as a political and cultural entrepreneur, one who seeks to channel the loose symbolic work performed by young people towards the pursuit of broader political causes. He is keenly aware that youth cultures usually involve only diffuse forms of resistance. This often leads to conflicts with authorities that are localized, sometimes violently self-destructive, and that have little strategic value. While Aboriginal youth resistance might be rooted in, and a product of, larger structures of oppression, it does not necessarily take direct aim at those structures. Vince is 
seeking to conscript the iconoclasm and anger of Aboriginal hip hop for the larger struggle to which he has devoted his life. His commitment to organizing the festival in the place where much Aboriginal policy is made shows he views this music as part of a larger agenda of Aboriginal protest. But does this do justice to the cultural complexity of Indigenous hip hop?

\section{Scene 2}

Bill is director of an Aboriginal education centre, a trained teacher who commutes each day from the outer suburbs to the centre in RW. We are speaking with him about creative training courses that his organization provides and the conversation drifts towards music.

I don't like all this American gang culture that comes with hip hop. It's setting blackfella against blackfella. Koori kids are fighting each other ... brothers and cousins. They're all wannabe gangstas.

Bill, born and raised in Gunnedah, western NSW, has lived for some time in a suburban area away from RW; he has a non-Indigenous wife and has much invested in the narrative of conformity to educational discipline and something of a disdain for cultural influences that he sees as encouraging resistance to educational institutions. He has little time for Aboriginal boxing world champion and hip hop artist Anthony Mundine and his 'flash black' public persona. Mundine flaunts his wealth and success in a caricature of acquisitive individualism in the same way LA gangsta rappers hold up the American dream to derision, defying conventional and conformist pathways to success and raising the model of the resistant subcultural career as offering the chance to escape social marginalization. Despite misogynistic and avaricious messages associated with some forms of mainstream hip hop, the success-through-resistance narrative clearly has some appeal to young Aboriginal men. This frustrates Bill who sees some degree of conformity (in work and education) as the only hope for Aboriginal youth.

\section{Scene 3}

Robert runs a small recording studio out of his flat in Newtown and encourages young Aboriginal men to learn performance and technical skills by producing and recording hip hop. In his thirties, he sees his role as pastoral: he mentors those who visit him and seeks to distract them from the temptations and dangers of the street. He has very 
strong feelings about what is authentic Aboriginal hip hop sound and points out material on MySpace and YouTube. The songs are expressions of urban warrior masculinity, part angry separatism, encouraging resistance, but also music encouraging pride and seeking to communicate the message of survival. Robert rejects ideas that hip hop should be delivered in Australian vernacular (a colonial imposition anyway, he argues) and sees nothing wrong with mimicking the accents and gestures of Afro American performers. It is apparent in our conversation that Robert is critical of some hip hop performers and those critics/producers/radio announcers/gatekeepers in the Aboriginal media who he feels are excluding certain sounds and messages. $\mathrm{He}$ is critical of Wire MC, for example. His energetic sectarian engagement with others involved in Indigenous hip hop indicates that there is something more at stake here than simply music. Robert positions himself not only as a critic but as one engaged in struggle over the political meanings of the art form associated with his role as Aboriginal activist.

\section{Conclusions}

Several commentators have challenged simplistic conceptions of identity and the reductive politics that flow from such understandings. Little has been written on this theme, however, about indigeneity. Political and cultural representations of first peoples in settler societies often appear reductive and unassailable; as if indigeneity is guaranteed, of essence, to be the principal source of identification. We have argued here that Indigenous peoples in modern societies are open to a range of interpellations, potential identifications and cultural influences. They are no less affected by circuits of contemporary culture and post-colonial processes than are, for example, immigrants to the West from the global south.

Existing residual solidarities are not reproduced automatically. This requires ongoing cultural and political work. Australian Aboriginal youth, like most young people in late modernity, are symbolically creative, pushing against both the received wisdom of elders, and the wider exercise of social power. Hip hop appeals to them, as it does to minority youth around the world, because it provides a resistant performativity, a street poetics that is simultaneously an account of, and response to, larger sources of oppressive authority.

Yet the production of Aboriginal hip hop is a politically and culturally complicated process. It is more than simply a sub-genre of a global subculture. Rather Aboriginal mentors play a key role in using hip hop to bridge between alienated youth and the wider Indigenous social order, in which homage is paid to the Aboriginal movement and 
its political achievements. However, we have argued that there is no single version of Aboriginal hip hop, and nor is there consensus about its political meaning. These assumptions, circulated within popular and academic analysis, are both naïve and unrepresentative. Rather our research indicates that the function of this sort of cultural work is to reproduce collectivities, to renew the symbolic repertoires through which they are defined, and, crucially, to channel the inchoate rebelliousness of young people in the direction of protest politics.

\section{Note}

1. We are grateful for the assistance of Cameron White, Pariece Nelligan, Ray Munro and Simon Jovanovic in researching this paper.

\section{References}

ALIM, H. SAMY 2007 Critical Hip-hop language pedagogies: combat, consciousness, and the cultural politics of communication', Journal of Language, Identity and Education, vol. 6, no. 2, pp. $161-76$

ALIM, H. SAMY, IBRAHIM, AWAD and PENNYCOOK, ALISTAIR 2009 Global Linguistic Flows: Hip Hop Cultures, Youth Identities, and the Politics of Language, New York: Routledge

ANDERSON, KAY 1993 'Constructing geographies: race, place and the making of Sydney's Aboriginal Redfern', in P. Jackson and J. Penrose (eds), Constructions of Race, Place and Nation, London: UCL Press

AUSTRALIAN BUREAU OF STATISTICS 2006 Census: Community profile series Shoalhaven local government area

BECK, ULRICK 1992 Risk Society: Towards a New Modernity, London: Sage

BENNETT, ANDY 1999 'Subcultures or neo-tribes? Rethinking the relationship between youth, style and musical taste', Sociology, vol. 33, no. 3, pp. 599-617

BENNETT, ANDY and KAHN-HARRIS, K. (eds) 2004 After Subculture: Critical Studies in Contemporary Youth Culture, London: Palgrave

BRUBAKER, ROGERS 2004 Ethnicity Without Groups, Cambridge, MA: Harvard University Press

BRUBAKER, ROGERS and COOPER, FREDERICK 2000 'Beyond "Identity", Theory and Society, vol. 29, pp. 1-47

BRUBAKER, R., FEISCHMIDT, MARGIT, FOX, JON and GRANCEA, LIANA 2006

Nationalist Politics and Everyday Ethnicity in a Transylvanian Town, Princeton, NJ: Princeton University Press

DAWES, GRAHAM 1998 'The art of the body: Aboriginal and Torres Strait Islander youth subcultural practices', Journal of Intercultural Studies, vol. 19, no. 1, pp. 21-35

DUNBAR-HALl, PETER And GIBSON, CHRIS 2004 Deadly Sounds, Deadly Places: Contemporary Aboriginal Music in Australia, Sydney: UNSW Press FORMAN, MURRAY 2002 The 'Hood Comes First: Race, Space, and Place in Rap and Hip Hop, Middletown, CT: Wesleyan University Press

FRASER, NANCY 2000 'Rethinking recognition', New Left Review, vol. 3, pp. 107-20

GIDDENS, ANTHONY 1991 Modernity and Self-Identity: Self and Society in the Late Modern Age, Cambridge: Polity

GORMAN-MURRAY, ANDREW 2006 'Homeboys: uses of home by gay Australian men', Social and Cultural Geography, vol. 7, no. 1, pp. 53-69 
HALL, STUART and JEFFERSON, TONY 1976 Resistance through Rituals, London: Hutchinson

HANNERZ, ULF 1992 Cultural Complexity, New York: Columbia University Press

HAYWARD, PHILlIP 1998 Sound Alliances: Indigenous Peoples, Cultural Politics, and Popular Music in the Pacific, London: Cassell

HEBDIGE, DICK 1979 Subculture: The Meaning of Style, London: Routledge

KITWANA, BAKARI 2003 The Hip Hop Generation: Young Blacks and the Crisis in African American Culture, New York: Basic Books

LOCAL NOISE 2006 Interview with Wire MC, http://www.localnoise.net.au/interviews/ wire-mc-interview/

MCDOWELL, LINDA 2003 Redundant Masculinities? Employment Change and White Working Class Youth, Oxford: Blackwell

MITCHELL, TONY 2002 Global Noise: Rap and Hip Hop Outside the US, Middletown, CT: Wesleyan University Press

2006 'Blackfellas rapping, breaking and writing: a short history of Aboriginal hip hop', Aboriginal History, vol. 30, pp. 124-37

MORGAN, GEORGE 2006 Unsettled Places: Aboriginal People and Urbanisation in New South Wales, Adelaide: Wakefield Press

NAYAK, ANOOP 2003 Race, Place and Globalization: Youth Cultures in a Changing World, London: Berg

NOTARPIETRO-CLARKE, CRISTINA 2007 'Blackfella beats and new flows', Arena Magazine, February

PEDDIE, IAN 2005 The Resisting Muse: Popular Music and Social Protest, Aldershot: Ashgate

REDFERN WATERLOO AUTHORITY 2006 Redfern and Waterloo employment and enterprise plan, http://www.redfernwaterloo.nsw.gov.au/other/final_eep_july06.pdf SHAW, WENDY 2008 Cities of Whiteness, New York: Blackwell SHILDRICK, TRACY and MACDONALD, ROB 2006 'In defence of subculture: young people, leisure and social divisions', Journal of Youth Studies, vol. 9, no. 2, pp. 125-40

SHOALHAVEN COUNCIL ECONOMIC DEVELOPMENT STRATEGY 2005 www.shoalhaven.nsw.gov.au/council/. . /ShoalEconomicDevtStrategy.pdf

STAVRIAS, GEORGE 2005 'Dropping conscious beats and flows: Aboriginal hip hop and youth identity', Australian Aboriginal Studies, vol. 2, pp. 44-54

THOMAS, NICHOLAS 1991 Entangled Objects: Exchange, Material Culture, and Colonialism in the Pacific, Cambridge, MA: Harvard University Press

THORNTON, SARAH 1996 Club Cultures: Music, Media and Subcultural Capital, Hanover, NH: Wesleyan University Press

WATSON, IAN, BUCHANAN, JOHN, CAMPBELL, IAN and BRIGGS, CHRIS 2003 Fragmented Futures: New Challenges in Working Life, Sydney: Federation Press

WHITE, CAMERON 2009 'Rapper on a rampage: theorising the political significance of Aboriginal Australian hip hop and reggae', Transforming Cultures E Journal, vol. 4, no. 1, pp. $108-30$

WILES, JANINE, ROSENBERG, MARK and KEARNS, ROBIN 2005 'Narrative analysis as a strategy for understanding interview talk in geographic research', Area, vol. 37, no. 1, pp. $89-99$

WILLIS, PAUL 1990 Common Culture: Symbolic Work at Play in the Everyday Cultures of the Young, Milton Keynes: Open University Press

YOUNG, IRIS MARION 1990 'City life and difference', in P. Kasinitz (ed.), Metropolis: Centre and Symbol of Our Times, Princeton: Princeton University Press 
GEORGE MORGAN is Senior Lecturer at the Centre for Cultural Research, University of Western Sydney.

ADDRESS: School of Humanities and Languages, Locked Bag 1797, Penrith South DC, NSW 1797, Australia.

Email: george.morgan@uws.edu.au

ANDREW WARREN is a PhD student in the School of Earth and Environmental Sciences at the University of Wollongong.

ADDRESS: School of Earth and Environmental Sciences, University of Wollongong, Wollongong NSW 2522, Australia.

Email: atw77@uow.edu.au 